\title{
The Role of Library and Public Policy Making In Making in Nigeria
}

\author{
Doris U. Aghoghovwia, \\ M.Sc (Library And Information Science) Senior Librarian Delta State College Of Education, Warri,Nigeria
}

Abstract: This paper examined the definition of public policy and the roles libraries are expected to play in its formulation. The obstacles to policy formulation and implementation were identified and solutions were proffered.

\section{Introduction}

Policies are essential to the success of human endeavours. This is so because they clarify existing conditions and objectives, and articulate important actions and strategies to reach the desired goals. They involve taking the necessary actions, evaluating their outcomes and impact, drawing lessons to guide future conduct and performance and varying what to be done in the light of the lesson. The failure of policy could be more dangerous in that it worsen the said living conditions. Nigeria's poor socio-economics conditions since the attainment of political independence has been ascribed to a variety of causes. Prominent among these, is policy failure (Ogunsola, 2008). It has been advanced that Nigeria has no difficulties with plan and policy formulation rather; the problem lies with policy implementation. Suffice to say that, both policy formulation and implementation are complementary facts of the process. Unless we cultivate this complementarily and take a holistic perspective of the policy process, we cannot achieve the desired policy success. Puting other words, an isolatory good performance in the area without the other translates invariably to over all failure.

Policy errors always occur at the formulation level due to inadequate policy analysis and inaccurate and on untimely data. This is where the provision of adequate library resource comes in since most of the adequate policy analysis and timely and relevant information are found in well-funded and adequate libraries. The world's intellectual output would be useless, even constitute nuisance, if libraries' were not there to gather, analyze, classify, catalogue and provide access to them. Different researches have shown that libraries contributed to the effectiveness of the process. Learners from institution where library use is part of the learning process are more equipped for the society and occupational effectiveness than those without proper library habit. Community members use library services and library programmes for everything from introducing their children to the habit and Joy of reading, to tapping into their professional networks (McClure, et al., 2000).

Furthermore, implementation problems lead to a wide range of issues such as corruption, lack of will to execute emergence of unforeseen difficulties derived from inadequate analysis, adverse internal and external shocks and sabotage and above all, inadequate library materials for reference purposes. Other problems arise. The cumulative of the foregoing is the apparent and emergent Nigeria paradox of a country rich in resources while the citizens are predominantly poor.

It is the objective of this paper to appraise the importance of policy and the need for adequate and functional library resources in its formulation. This paper will also indentify problems and proffer solutions to them.

\section{What Is Public Policy?}

The Longman's Dictionary of Contemporary English defines policy as "a plan or course of action in directing affairs, as chosen by a Political party, government, Business Company, etc. Policy can also be referred to as substantive programmes referring specifically to the content of what is to be done. In this sense, policy answers questions such as what do you do in this organization? And what kinds of issues or problems do you deal with?. The policy of government entails both conceptions in terms of the "what" and "how" of government activities. Policies relative to government's decision making. Policy may be conceived as the course of action by government towards an aspect of the economy, including the goals of government methods to pursue such goals. In general terms, policy implies state intervention in the economy. They are purposeful statement written or oral, aimed at solving a particular problem.

It is important to note that some policies could be oral statement, according to Gitu (2001).Some policies could be oral statement because very often, policies are pronounced even when they have not be articulate in writing or are enacted without being written. In reality, policy consists of course of actions and measure deliberate actions taken in order to direct the affairs of society towards the realization of predetermined 
goals or objectives of development. Public policies thus aim to promote social well being, good governance and development. They deal with a wide range of societies issues-economics, social, cultural, political, scientific and technological and environmental. For example in agriculture, industry, defense, health, population, social welfare, education, transportation, utilities, housing, environment, political structure and organizations, law and order, and regulation of economic and social activities. At the economic level, public policy is usually of two or more categories. They are the macro-economic policies which concern the economy as a whole. There is the micro-economics, which are concerned with how the individual sectors of the economy can perform better. There is other vital aspect of public policy, which are not linked to economic consideration for example policies that have to do with the following such as education, health, population, social welfare, the environment, etc. There is also the political dimension of policy (Suberu, 1999), which concern the issue of reorganization; redistribution or rational symbolism. Policy is the process by which the government develops and implements an effective strategy to meet desired goals. In this case, strategy is the unified comprehensive plan that is developed to reach these goals. The policy formulation process entails the determination of the policy problems, policy content, design of implementation strategies and monitoring, review and revision of strategy. The strategy chosen must be derived from the social value or philosophy which informs the policy and must be clearly and specifically linked with the goals of policy (Ekaete, 2001).

Thus, from the above, it is clear that the economic policy of any government is predicated on the strategy of the private sector playing a dominant role in the economy while government provides the enabling environment.

The philosophy of governance is an essential determinant of the structure of public policy. This means that public policies at all times must be geared towards the advancement of the security and welfare of the people.

\section{Roles of Libraries and Public Policy}

Libraries functions involve the collection, processing, storage, and dissemination of recorded information for the purpose of reading; study and consultation by users. For a library to achieve the above, it entails different activities which translate into library and information services. Over the years, external environment has been having a tremendous impact on the practice of the profession. Aina (2004) opined that library and information profession borrows from a number of disciplines such as computer science, business, management, mathematics, statistics, marketing etc. Thus, anything that impacts on any of these disciplines would have direct influences on library and information science profession. This also happens to public policy because for a public policy by any government or organization to be successful and meaningful, the role of library can never be over emphasized Libraries enhance productivity of individuals and organizations. Access to the right information is a very crucial component in the productivity of information workers and consequently, the productivity and good decision making of the organizations that employed them. For the self-employed knowledge workers use of the Libraries make them more productive on their jobs, especially, as they can obtain job related training in the areas of computer and information literary skills and good business practices (Bolt, 1991) Keyes, 1995). Another external factor impacting on the profession is modern management techniques such as strategic management, quality management, etc. Quality management involves quality control, quality assurance and total quantity management. These are concepts that are now frequently used in library and information profession hence, libraries and public policy formulation and implementation cannot be separated for a successful public policy by any government or organization. It should be noted that library and information science profession is one of the fastest growing profession in the world. Information is the biggest industries in some developed countries like U.S.A. and United Kingdom. Research is on, all the time to improve library and information science and the professional librarian is expected to keep pace with the new findings and products in the profession Mcclure, etal (2000) opined that only people and business in the higher income bracket are able to afford the hardware, software and connectivity costs required to participate in the information revolution, including e-commerce. Access to interment should not be limited to higher income earners; however, the library is well positioned to help bridge the economic gap along with the digital divide. For individual who could not afford computer technology at home, the library can help to provide the necessary connections in order to avoid the division of our society into information "haves and have nots". In the western style, there is universal access which is not practical in African countries instead; focus should be on providing access through community facilities like libraries and schools (Gambao et al, 2001). More so when it is clear, those people and nations who cannot or will not participate fully in the new information economy will find it hard to climb out of poverty, books are a chance for people to better themselves. According to Ogunsola (2008) just as books are freely available from libraries, the door of libraries should lead everyone to cyberspace too-free. In the information society this real chance for equality of opportunity through libraries should remain. Thus, libraries will not only provide internet access points, also, places where people may receive help in using internet and other information sources. 
Libraries worldwide since the least two decades have undergone significant change from a purely traditional modeled manual services delivery system to a more dynamic technology driven system. As revealed by Akintunde (2004) the vocabulary of librarianship is changing. Disseminationis being replaced by "Communication", "repository" by "data", literature" by "knowledge" "search" by "navigation? Etc .This reflects current approach to packaging and the tools used for managing knowledge. Knowledge itself has become more ambiguous than was ever imagine twenty years ago more importantly, library has become globalized in terms of the actual setting of, and access to resources. For any sound public policy to be formulated and implemented, modern library resources can play a tremendous role. Today Library is technologically driven one that uses the principles of traditional library services to organize knowledge and communicate it to clients in global community. The ability of librarians to acquire necessary skills and deploy them in their job of preparing public policy development can save a lot of money for the government since there would be no need to hire and pay consultant to do the tasks. Libraries have become integral part of ICT in education, health, governance and public and social services.

Furthermore, the status of the librarian has soured because of their abilities and potential to organize knowledge and communicate this in most acceptable format to users. At this junction, one can ask if the libraries in Africa can take rightful place in policy or economic development. The answer to this question is yes and no depending on the locality, but the fact is that most African libraries are in crisis.Between1960 and 1980, libraries in Africa were built and resourced with determination in the hope that they would support the rapid development of their communities. Then, national governments, donors and organizations funded libraries as their basic needs but since 1980s, libraries across Africa have experienced a very deep decline in resources and services. This is due to inadequate fund most libraries do not get up to half of their minimum requirements. One of the reasons why illiteracy rate is high in developing countries like Nigeria is because many people like civil servants relapse into secondary illiteracy for want of adequate and relevant reading materials to sustain and consolidate the reading skills acquired in the class room (Ogunsola, 2004). Suffice to say that, youth and workers of today will be creative, informed and knowledgeable, will be shaped by the boundaries of the content of the library resources available within their environment or organization.

If libraries are to take their place in public policy formulation their functions should be based on information system as pointed out by Osundina (1973). The library of today should not merely store documents and preserve them; it must also devise means by which the contents of such documents can be rapidly and effectively transmitted for use. It must be noted that the pace of change brought by new technologies has had a significant effect on the way people live, work and play worldwide.

This is why the importance of libraries in providing the enabling environment for public policy formulation becomes important. The progress of any nation as revealed by Badewi (2004) depends on the development of its people through education. The development of education on the other hand may be said to be synonymous with the development of libraries and its services within a given community. Libraries can only help to bring about social development, if and when the people within the communities make regular use of library and its resources. It is the realization of this great power of information that made libraries and information resources center inevitably present in all sectors of a nation's economy. Hence today, libraries are found in all the three level of our educational system, public, research institutions and private organizations such as banks, insurance company, manufacturing companies, etc so the role of libraries and librarians in the concept of public policy formulation and implementation can never be over emphasized.

\section{Problems of formulation and Implementation of Public Policy in Nigeria}

Public policies are meant to address the numerous problem and concerns of societies. They can be simple or complicated depending on the nature of the problem. Making economic policy is more completed than promulgating laws or regulations. According to Wolgu, (1997) some major policies can be changed by the "stoke of pen", most require a continuous and difficult period of formulation, analysis and implementation for examples privatization policy and civil service reform require high degree of technical competence to go along with the political will.

Public policy requires wide consultation prior to the initiation of policy and involvement of stakeholders in policy implementation. But in Nigeria, it is sad to note that majority of the people whom the policy is meant for are not well informed because they lack reading habits and inadequate library resources in their locality. For instance, majority of the population cannot afford a copy of newspaper or magazine and the only libraries they can run to for necessary information are being neglected or they are not in existence at all. It must be noted that most of the public and government libraries in Nigeria today are on the verge of collapse because of government long neglect as a result of economic down turn in the last two decades. This is the reasons our public policies usually run in to trouble since they are not based on empirical research and adequate data and information. 
One of the ways which government can overcome the above problems is to provide well funded library resources both for our public and tertiary institutions. It must be noted that the present state of libraries throughout the country has nothing to offer because they have been neglected by government for a long time. Policy research helps policy analysis. Good research is necessary to formulate good policy. Policy research also helps policy makers to discover new area of emphasis. Further, it enables them to assess the success with which earlier policy target and objectives have been met or not and the potential impact of policy options (Gitu, 2001). However, it should be noted that any research is synonymous with adequate library resources. Thus, without good libraries no meaningful research can be carried out. This is so because for any research to be relevant for policy decision making, it must have these features: saliency, credibility and legitimacy. The role of expert/technocrats in the policy profess cannot be ignored. They are involved in the policy process by supplying information and articulating the broad objectives that guides policy direction. The advice of expert can also lead to the initiation of policies by decision makers or politicians, apart from the vision of the government itself. In addition, expert assist wilt the scientific management of the policy process through policy analysis. All these functions are made possible, because these experts are backed with modern library resources.

\section{Conclusion And Recommendations}

People are resistant to change due to fear of the unknown if good reforms are to be achieved; there must be a political will on the part of all concerned to sustain them. Many economic and social problems in the country have subsisted because of weakness in public policy formulation and implementations. Some of the weakness and problems are as a result of inadequate information and data leading to "Planning without facts" and also, most policy decision and statement are not predicated on sound analysis. All these weakness and problems are partly due to lack of adequate library resources, which provides enabling environment for people in charge of policy formulations and implementation. Government should therefore provide adequate modern library resources that will and policy researchers have access to information resources that will lead them relevant information and data needed in public policy process.

The general public, the private sector and other stakeholders should be committed to the policy process. The policy process should be backed by strong institutional commitment for it to be well implemented. The government should also, nurture the reservoir of knowledge and skills available locally to benefit national policy making by encouraging close interface with local universities and training and research institutes known for relatively and adequate and functioning library resources.

The Government and private organizations, such as the chambers of commerce, should strive to provide a formal institutional framework to support cooperation between researchers, policy makers and representatives of business and entrepreneurial interest. In this connection, there should be institutional arrangements for regular interactions between government, the private sectors and research institutions. In addition, the government should establish formal institutional channels to support cooperation and regular interactions between researchers and indigenous think-tanks, on the one hand, and policy makers and implementation, on the other. Workshops and seminars should be organized on regular basis at which researchers' and policy makers could interact and discuss common policy issues and problems.

Proceedings from such workshops and seminars should be made available in our various libraries for future reference.

As government is becoming more complicated by demand of every sector of the economy and international concern, the art of policy-making demands greater attention in order to improve the quality of policy and ensure sustained development. Therefore, the investigative and administrative personnel of government must be improved for greater task in policy making. One of the ways to do this is for the government, research organizations and other stake holders to pay more attention to adequate and provision of library facilities in the country because policy makers heavily depend on adequate information. Research is the process of discovering new or additional useful information. It is central to the policy making process in the effort to bring out sustained development. The need for research derives from either insufficient information, which does not lead policy makers to definite conclusion and policy direction, or lack of information on an issue of public concern for which a policy action is eventually desirable. But it must be realized that realized that research is tantamount with library facilities and without adequate library provision, successful research cannot be meaningfully carried out. So every hands must be on deck to see that necessary attentions given to library provision by both the government and other stakeholders in the public policy development in Nigeria.

\section{References}


[1] Aina, L. O. (2004)"Coping with the challenges of Library and Information Services Delivery: the need for Institutionalized Professional Development". Paper delivered at the Nigerian Library Association $42^{\text {nd }}$ National Conference and AGM at Akure, Nigeria between June $20^{\text {th }}-25^{\text {th }}, 2004$, pp.5

[2] Akintunde, Stephen A. (2004) "Libraries as tools for ICT Development". Paper delivered at the Nigerian Library Association $42^{\text {nd }}$ National Conference and AGM held at Akuru, Nigeria from June $20^{\text {th }}-25^{\text {th }}, 2004$, pp. 10.

[3] Badawi, GhajiAbubakar (2004) "Libraries as Tools for Promoting Education in the Society: An Analysis of Library Utilization by women in Kano State:. Paper delivered at the Nigerian Library Association $42^{\text {nd }}$ National conference and AGM held at Akure, Nigeria from June $20^{\text {th }}-25^{\text {th }}, 2004$, pp.19

[4] Bolt, Nancy. (1991) "Libraries, public policy, and economic development" literacy administration and Management. Vol, 5, no. 2, pp. $81-85$

[5] Ekaete, U.J (2001) "Concepts of Public Policy". In" David Sills, ed. International Encyclopedia of the Social Science vol. 13 and 14, pp. 204. New York: the Macmillian Company and Freee Press.

[6] Gomboa, Carlos A, laporte, Ron, and Francis Souer. (2001). "Reaching the Last Mile" cooperation South, Number 1of 2001: 92. (Special issue on ICT for development).

[7] Gitu, K.W. (2001) "Strengthening the Link Between Policy Research and Implementation" Occasional paper, No. 1, of the Kenya Institute for public policy Research and Analysis, my. Pp. 2

[8] Keyes, Alison M (1995). "The value of the special library: review and analysis. Special Libraries. Vol. 85, no 3. Pp. 182-187.

[9] McClure, Charles R, Bruce T. Franzer, Timothy W Nelson and Jone B. Robbins (2000). Economic benefit and impact from Public Libraries. Final Report. Tallahassee: state Library of Florida.

[10] Ogunsoloa, L.A. (2004):"Adequate Library Facilities in Nigeria: A key contributor to Sustainable Distance Education System. Journal of Social Science, 9 (i) pp. 24.

[11] Osundina, O. (1973) "the Relationship between information science librarianship: a viewpoint Nigeria Libraries. Vol. 9, no 1\&2, pp47

[12] Suberu, S.T. (1999) "Public Policies and National Utility in Nigeria”. Development Policy Centre Research Report, no. 19, Ibadan, Nigeria.

[13] Ogusola, L.A (2008): "The role of library facilities in the public Policy making in Nigeria".

[14] Ozean Journal of social Sciences, 1 (1) pp.21-28

[15] Wolgu, J.M. (1997) "The Evolution of Economic policy Making in Africa". America Economic Association Papers and proceeding (May). Pp.54 